\title{
Photocatalytic Formic Acid Conversion on CdS Nanocrystals with Controllable Selectivity for $\mathrm{H}_{2}$ or $\mathrm{CO}^{* *}$
}

\author{
Moritz F. Kuehnel, David W. Wakerley, Katherine L. Orchard, and Erwin Reisner*
}

\begin{abstract}
Formic acid is considered a promising energy carrier and hydrogen storage material for a carbon-neutral economy. We present an inexpensive system for the selective roomtemperature photocatalytic conversion of formic acid into either hydrogen or carbon monoxide. Under visible-light irradiation $(\lambda>420 \mathrm{~nm}, 1$ sun), suspensions of ligand-capped cadmium sulfide nanocrystals in formic acid/sodium formate release up to $116 \pm 14 \mathrm{mmol} \mathrm{H}_{2} \mathrm{~g}_{\text {cat }}{ }^{-1} \mathrm{~h}^{-1}$ with $>99 \%$ selectivity when combined with a cobalt co-catalyst; the quantum yield at $\lambda=460 \mathrm{~nm}$ was $21.2 \pm 2.7 \%$. In the absence of capping ligands, suspensions of the same photocatalyst in aqueous

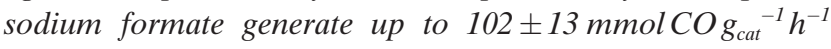
with $>95 \%$ selectivity and $19.7 \pm 2.7 \%$ quantum yield. $\mathrm{H}_{2}$ and $C O$ production was sustained for more than one week with turnover numbers greater than $6 \times 10^{5}$ and $3 \times 10^{6}$, respectively.
\end{abstract}

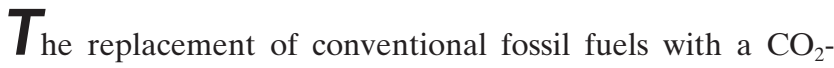
neutral energy cycle is a key global challenge for developing a sustainable economy. Hydrogen holds promise as a secondary energy vector for use in fuel cells, but its safe storage and transport remain the subject of intensive research ${ }^{[1]}$ Formic acid $\left(\mathrm{HCO}_{2} \mathrm{H}, \mathrm{FA}\right)$ has received considerable attention as

[*] Dr. M. F. Kuehnel, ${ }^{[+]}$D. W. Wakerley, ${ }^{[+]}$Dr. K. L. Orchard, Dr. E. Reisner

Christian Doppler Laboratory for Sustainable SynGas Chemistry Department of Chemistry, University of Cambridge

Lensfield Road, CB2 1EW, Cambridge (UK)

E-mail: reisner@ch.cam.ac.uk

Homepage: http://www-reisner.ch.cam.ac.uk

$\left[{ }^{+}\right]$These authors contributed equally to this work.

[***] This work was supported by the Christian Doppler Research Association (Austrian Federal Ministry of Science, Research, and Economy and the National Foundation for Research, Technology and Development), the OMV Group, the EPSRC (EP/H00338X/2 to E.R.), the Isaac Newton Trust, the German Research Foundation (M.F.K.), and the Advanced Institute for Materials ResearchCambridge Joint Research Centre (K.L.O.). XPS spectra were obtained at the National EPSRC XPS User's Service (NEXUS) at Newcastle University, an EPSRC Mid-Range Facility. We thank Dr. Christine A. Caputo and Georgina A. M. Hutton for helpful discussions and Benjamin C. M. Martindale for help with XPS spectroscopy. Additional data related to this publication is available at the University of Cambridge data repository (http://www. repository.cam.ac.uk/handle/1810/248441).

$\square$ sup Supporting information for this article is available on the WWW under http://dx.doi.org/10.1002/anie.201502773.

o $\mathrm{KGaA}$. This is an open access article under the terms of the Creative Commons Attribution License, which permits use, distribution and reproduction in any medium, provided the original work is properly cited. a potential renewable fuel of high energy density. Its low toxicity and high gravimetric hydrogen content of $4.4 \%$ render FA a promising hydrogen storage material, with $\mathrm{CO}_{2}$ as the only by-product of $\mathrm{H}_{2}$ release. ${ }^{[2]} \mathrm{CO}_{2}$ recycling by mild homogeneous hydrogenation of $\mathrm{CO}_{2}$ to FA has become a feasible process to store $\mathrm{H}_{2}$ derived from renewable sources. $^{[3]}$ In addition, a growing number of synthetic catalysts $^{[4]}$ and enzymes ${ }^{[5]}$ promote the storage of electrical energy by electrochemical reduction of $\mathrm{CO}_{2}$ to FA. FA is also a major product of biomass processing. ${ }^{[6]}$

Although FA dehydrogenation (FA-to- $\mathrm{H}_{2}$ ) is an exergonic process (Scheme 1), efficient liberation of $\mathrm{H}_{2}$ requires additional energy input (i.e. high temperatures or light) unless precious-metal-based catalysts are employed. ${ }^{[7,8]}$ The high

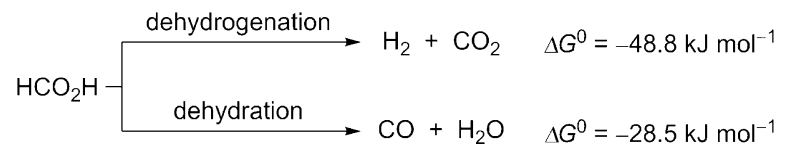

Scheme 1. Thermodynamics of formic acid decomposition pathways. ${ }^{[16]}$

cost and low abundance of these catalysts, however, precludes scalability and thus a widespread application. Precious-metalfree alternatives typically require elevated temperatures and organic solvents, limiting their potential use in portable applications and decreasing their overall energy density. ${ }^{[9]}$ Only recently, the photochemical decomposition of FA has attracted increasing interest as an alternative approach to generate $\mathrm{H}_{2}$ from FA at room temperature. Photocatalysts based on $\mathrm{Pd},{ }^{[10]} \mathrm{AuPd},{ }^{[11]} \mathrm{Pt},{ }^{[12]} \mathrm{Rh}^{[13]}$ and $\mathrm{Ru}^{[14]}$ have demonstrated activities up to $154 \mathrm{mmol} \mathrm{H}_{2} \mathrm{~g}_{\text {cat }}{ }^{-1} \mathrm{~h}^{-1}$. Examples of precious-metal-free catalysts are scarce and show substantially lower activity. ${ }^{[15]}$

Despite the pivotal role of nanocrystalline semiconductors (commonly referred to as quantum dots, QDs) ${ }^{[17]}$ in photovoltaics $^{[18]}$ and artificial photosynthesis, ${ }^{[19]}$ little is known about their activity towards photochemical FA-to- $\mathrm{H}_{2}$ conversion. Cadmium sulfide is among the most studied QD materials owing to its ease of preparation, low cost, and high absorption of visible light. Whereas bulk CdS powder shows limited photocatalytic FA-to- $\mathrm{H}_{2}$ activity, ${ }^{[20]}$ enhanced activity has been achieved by confinement on a titanate nanotube support, ${ }^{[21]}$ by construction of CdS-ZnS heterojunctions, ${ }^{[22]}$ and by introduction of precious-metal co-catalysts such as $\mathrm{Pt}^{[21 \mathrm{a}, 23]}$ and $\mathrm{Ru} .{ }^{[22,24]}$ A precious-metal-free hybrid system comprised of $\mathrm{CdS}$ and a $\mathrm{H}_{2}$-producing enzyme (hydrogenase) exhibited low selectivity and suffered from enzyme inhibition. ${ }^{[25]}$ Moreover, none of these systems show flexibility with respect to the reaction products. 
FA is known to undergo two pathways of decomposition, to give either $\mathrm{H}_{2}$ or carbon monoxide (Scheme 1). $\mathrm{CO}$ is a valuable synthon in the chemical industry and synthesis gas (a mixture of $\mathrm{CO}$ and $\mathrm{H}_{2}$ ) can be used to generate liquid fuels such as methanol and hydrocarbons by the Fischer-Tropsch process. ${ }^{[2]} \mathrm{CO}$ is currently produced from fossil sources, but despite its critical importance, the sustainable generation of $\mathrm{CO}$ from $\mathrm{FA}$ has received little attention, and no chemical storage process for $\mathrm{CO}$ is currently available. ${ }^{[27]} \mathrm{FA}$ contains more than $60 \mathrm{wt} \% \mathrm{CO}$, which can be released upon treatment with excess dehydrating agents, such as conc. $\mathrm{H}_{2} \mathrm{SO}_{4}$, but catalytic FA-to-CO conversion typically requires high temperatures. ${ }^{[28]}$ Consequently, selective photocatalytic FA-to$\mathrm{CO}$ has not been reported. This work presents an inexpensive and highly active CdS-based photocatalyst that efficiently uses FA as a clean storage material for the controlled generation of either $\mathrm{H}_{2}$ or $\mathrm{CO}$ under ambient conditions.

Monodisperse $\mathrm{CdS}$ nanocrystals with 3-mercaptopropionic acid (MPA) capping ligands (QD-MPA) were prepared according to literature procedures from oleic acid capped CdS nanoparticles by basic ligand exchange $\left(\lambda_{\max }=443 \mathrm{~nm}, D=\right.$ $4.4 \pm 0.4 \mathrm{~nm}$, Figure S1). ${ }^{[19 \mathrm{c}, 29]}$ Under simulated solar light irradiation (AM1.5G, $100 \mathrm{~mW} \mathrm{~cm}^{-2}, \lambda>420 \mathrm{~nm}, 25^{\circ} \mathrm{C}$, see Supporting Information for details), dispersions of QD-MPA in $4.0 \mathrm{M}$ sodium formate in FA (Laboratory Reagent Grade, $>90 \%$ ) generated $\mathrm{H}_{2}$ at initial rates of $52.1 \pm$ $6.6 \mathrm{mmol} \mathrm{H}_{2} \mathrm{~g}_{\text {cat }}{ }^{-1} \mathrm{~h}^{-1}$ (Figure $1 \mathrm{~A}$, Table 1). The addition of up to $0.5 \mathrm{~mm} \mathrm{CoCl}_{2} \cdot 6 \mathrm{H}_{2} \mathrm{O}$ resulted in enhanced rates of up to $116 \pm 14 \mathrm{mmol} \mathrm{H}_{2} \mathrm{~g}_{\text {cat }}{ }^{-1} \mathrm{~h}^{-1}$ (QD/Co ratio ca. 500:1, see Figure S2 and Tables S1 and S2 for optimization details). Only traces of $\mathrm{CO}$ were detected in the headspace gas $(670 \pm$ $146 \mathrm{ppm}$ absolute, $0.614 \pm 0.065 \%$ with respect to $\mathrm{H}_{2}$ ). When the full solar spectrum was used for irradiation, the rate increased to $218 \pm 22 \mathrm{mmolH}_{2} \mathrm{~g}_{\text {cat }}{ }^{-1} \mathrm{~h}^{-1}$ (Figure S3), showing that both the visible and UV portion of the solar spectrum are used for catalysis; a dependence of the catalyst on light was confirmed by varying the light intensity (Figure S4). At $\lambda=460 \mathrm{~nm}$, the external quantum yield (EQY) was $21.2 \pm 2.7 \%$ (Table S3). The $\mathrm{CO}_{2} / \mathrm{H}_{2}$ ratio increased over time (Figure S5), but remained below the theoretical 1:1 stoichiometry (Scheme 1), presumably because of a higher
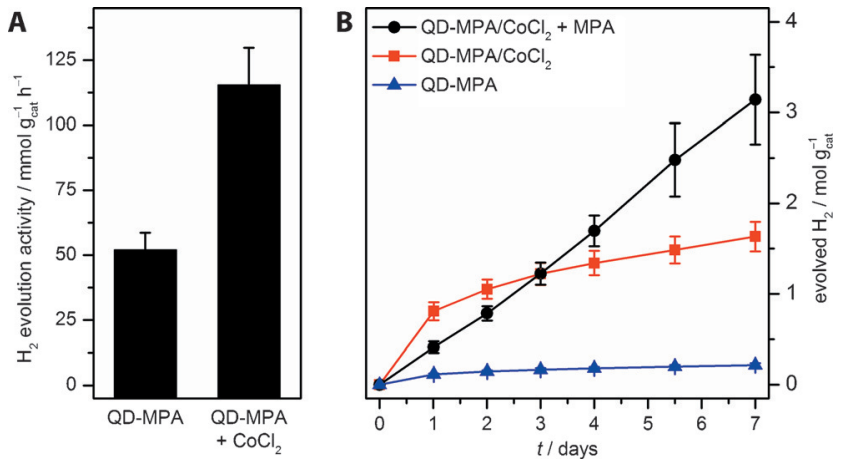

Figure 1. Photocatalytic dehydrogenation of FA: A) Initial activity of QD-MPA with and without added co-catalyst ( $1 \mathrm{~h}$ of irradiation); B) long-term activity of QD-MPA [AM1.5G, $100 \mathrm{~mW} \mathrm{~cm}^{-2}, \lambda>420 \mathrm{~nm}$; $0.91 \mu \mathrm{M}$ QD-MPA $\left(176 \mu \mathrm{g} \mathrm{mL}^{-1}\right), 4.0 \mathrm{M} \mathrm{NaHCO}_{2}$ in $\mathrm{FA} ; \mathrm{CoCl}_{2}=0.5 \mathrm{~mm}$ $\mathrm{CoCl}_{2} \cdot 6 \mathrm{H}_{2} \mathrm{O}, \mathrm{MPA}=140 \mathrm{~mm}$ 3-mercaptopropionic acid].

solubility of $\mathrm{CO}_{2}$ over $\mathrm{H}_{2}$ in FA. $\mathrm{H}_{2}$ generation even proceeds in FA without added sodium formate, albeit at a lower rate of $1.4 \pm 0.3 \mathrm{mmol} \mathrm{H}_{2} \mathrm{~g}_{\text {cat }}{ }^{-1} \mathrm{~h}^{-1}$. No $\mathrm{H}_{2}$ was formed in the dark or without photocatalyst (Table S2).

Long-term experiments were performed to demonstrate the stability of this system (Figure $1 \mathrm{~B}$, Table S4). $\mathrm{H}_{2}$ evolution was sustained for more than 7 days, even in the absence of a co-catalyst. The rate of $\mathrm{H}_{2}$ evolution gradually decreased during the first $48 \mathrm{~h}$ of irradiation, stabilizing at $4.4 \pm$ $1.3 \mathrm{mmol} \mathrm{H}_{2} \mathrm{~g}_{\text {cat }}{ }^{-1} \mathrm{~h}^{-1}$ and $0.52 \pm 0.17 \mathrm{mmol} \mathrm{H}_{2} \mathrm{~g}_{\text {cat }}{ }^{-1} \mathrm{~h}^{-1}$ with and without co-catalyst, respectively. When excess MPA $(140 \mathrm{~mm})$ was added to the QD-MPA/ $\mathrm{CoCl}_{2}$ system prior to irradiation, a lower initial rate of $18.7 \pm 2.9 \mathrm{mmol} \mathrm{H}_{2} \mathrm{~g}_{\text {cat }}{ }^{-1} \mathrm{~h}^{-1}$ was observed, but this activity remained constant over the course of one week. More than $3 \mathrm{~mol} \mathrm{H}_{2} \mathrm{~g}_{\text {cat }}{ }^{-1}$ were generated after one week, which corresponds to over 600000 turnovers per QD. Transmission electron microscopy (TEM) after photocatalysis indicated the formation of aggregates that retained nanocrystalline features (Figure S6). Particle aggregation over time was monitored in situ by UV/Vis spectroscopy. When QD-MPA is added to FA, a red-shift of the absorption maximum indicates aggregation, which increases further during irradiation (Figure S7 A) ${ }^{[30]}$ In the presence of

Table 1: Comparison of selected photocatalysts for visible-light-driven FA-to- $\mathrm{H}_{2}$ conversion under ambient conditions (see Table S5 for more examples).

\begin{tabular}{|c|c|c|c|c|c|}
\hline Catalyst & Activity $^{[\mathrm{a}]}\left[\mathrm{mmol} \mathrm{H}_{2} \mathrm{~g}_{\text {cat }}{ }^{-1} \mathrm{~h}^{-1}\right]$ & Selectivity $^{[\mathrm{b}]}[\%]$ & EQY [\%] & Lifetime [h] & Ref. \\
\hline $\mathrm{Pd}-\mathrm{C}_{3} \mathrm{~N}_{4}$ & 53.4 & 100 & $\mathrm{n} / \mathrm{a}$ & $>6$ & [10b] \\
\hline $\mathrm{AuPd}-\mathrm{TiO}_{2}$ & $17.7^{[c]}$ & 99.7 & 15.6 & $>9$ & [11b] \\
\hline Pt-CdS & 1.22 & $\mathrm{n} / \mathrm{a}$ & 21.4 & $>30$ & [23a] \\
\hline Ru-CdS/ZnS & $5.85 \pm 0.09$ & $\mathrm{n} / \mathrm{a}$ & 20 & $>40$ & {$[22]$} \\
\hline $\mathrm{CdS} / \mathrm{ZnS}$ & $1.24 \pm 0.02$ & $\mathrm{n} / \mathrm{a}$ & $\mathrm{n} / \mathrm{a}$ & $>40$ & {$[22]$} \\
\hline $\mathrm{H}_{2}$ ase- $C d S^{[d]}$ & 0.356 & 20 & 3.1 & $>3.5$ & {$[25]$} \\
\hline$\left[\left\{\mathrm{RuCl}_{2}(\mathrm{PhH})\right\}_{2}\right]+12 \mathrm{PPh}_{3}$ & $154^{[\mathrm{e}]}$ & $\mathrm{n} / \mathrm{a}$ & $\mathrm{n} / \mathrm{a}$ & $>5$ & [14] \\
\hline$\left[\mathrm{Fe}_{3}(\mathrm{CO})_{12}\right]+\mathrm{PPh}_{3}$, tpy $^{[\mathrm{ff}]}$ & $2.7^{[\mathrm{e}]}$ & "trace CO" & $\mathrm{n} / \mathrm{a}$ & $>24$ & {$[15 c]$} \\
\hline QD-MPA & $52.1 \pm 6.6$ & $98.8 \pm 0.1$ & $\mathrm{n} / \mathrm{a}$ & $>168$ & this work \\
\hline QD-MPA/CoCl 2 & $116 \pm 14$ & $99.4 \pm 0.1$ & $21.2 \pm 2.7$ & $>168$ & this work \\
\hline QD-MPA/CoCl 2 & $218 \pm 22^{[c]}$ & $98.9 \pm 0.1$ & $\mathrm{n} / \mathrm{a}$ & $>24$ & this work \\
\hline
\end{tabular}

[a] For an accurate comparison, published data were converted into gravimetric activity using the mass of the entire photocatalyst used in the reaction.

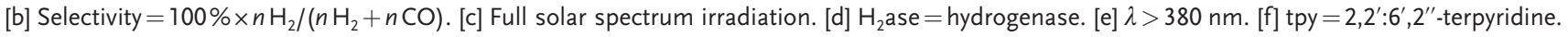
$\mathrm{n} / \mathrm{a}=$ not available. 
MPA, a red-shift was observed upon addition to FA, but no further change occurred during irradiation (Figure S7B), suggesting that MPA enhances the lifetime of QD-MPA during photocatalysis by preventing aggregation.

To the best of our knowledge, the catalytic activity and lifetime of QD-MPA/ $\mathrm{CoCl}_{2}$ surpasses all previously reported heterogeneous photocatalysts for FA-to- $\mathrm{H}_{2}$ conversion under ambient conditions, including those based on precious metals (Table 1, see Table S5 for a more comprehensive comparison). The most active heterogeneous catalyst to date, a Pd$\mathrm{C}_{3} \mathrm{~N}_{4}$ nanocomposite, evolves $53.4 \mathrm{mmol} \mathrm{H}_{2} \mathrm{~g}_{\text {cat }}{ }^{-1} \mathrm{~h}^{-1}$ with quantitative $\mathrm{H}_{2}$ selectivity for up to $6 \mathrm{~h}$. Without added cocatalyst, QD-MPA shows a comparable activity, whereas QD$\mathrm{MPA} / \mathrm{CoCl}_{2}$ is more than twice as active and shows an improved long-term stability. A Ru-based homogeneous photocatalyst was reported to achieve $154 \mathrm{mmol} \mathrm{H}_{2} \mathrm{~g}_{\text {cat }}{ }^{-1} \mathrm{~h}^{-1}$ in DMF solution, but no selectivity was reported. ${ }^{[14]}$ The best precious-metal-free photocatalyst, CdS-ZnS particles, can evolve up to $1.24 \pm 0.02 \mathrm{mmol} \mathrm{H}_{2} \mathrm{~g}_{\text {cat }}{ }^{-1} \mathrm{~h}^{-1}$ under irradiation with visible light (selectivity not reported), ${ }^{[22]}$ more than two orders of magnitude less than QD-MPA/ $\mathrm{CoCl}_{2}$.

Insight into the nature of the active catalyst was sought by separating QD-MPA/CoCl 2 from the reaction mixture by centrifugation after $1 \mathrm{~h}$ photocatalysis. When the solid residue was re-dispersed in fresh reaction medium without added cocatalyst, the observed $\mathrm{H}_{2}$ evolution activity was similar to QD-MPA in the absence of co-catalyst, suggesting that the active catalyst is not attached to the QDs. The QD-free supernatant did not show any activity (Figure S8, Table S6). Inductively coupled plasma optical emission spectrometry (ICP-OES) measurements of the solid confirm the absence of $\mathrm{Co}(\mathrm{Co} / \mathrm{Cd}$ atomic ratio in the solid less than $(4.8 \pm 1.9) \times$ $10^{-4}: 1$; in contrast to $0.44: 1$ in the entire sample before catalysis). These findings and the absence of an induction period for $\mathrm{H}_{2}$ evolution with QD-MPA/ $\mathrm{CoCl}_{2}$ lend further support to the homogeneous nature of the active co-catalyst. Cobalt species are known to function as homogeneous hydrogen-evolving catalysts in the presence of nanocrystalline semiconductors. ${ }^{[31]}$ Incorporation of cobalt is also known to enhance the activity of formate oxidation electrocatalysts $^{[32]}$ and there is precedent for homogeneous oxidation of FA by $\mathrm{Co}^{3+}$ ions. $^{[33]}$ The mechanism of FA-to- $\mathrm{H}_{2}$ conversion could, therefore, consist of formate oxidation by photogenerated holes and subsequent proton reduction by photoexcited electrons. ${ }^{[20,34]}$ In this case, the reductive half reaction, the oxidative half reaction, or both are enhanced by Co catalysis.

With the reactivity of nanocrystalline CdS towards formate established, we sought possibilities to tune the reaction pathway towards FA-to-CO conversion [Scheme 1, Eq. (2)]. In aqueous formate solution, the activity of QDMPA was much lower than in FA but showed a reversed selectivity, with $\mathrm{CO}$ as the main decomposition product $(60 \pm$ $7 \%$ CO, Figure 2 A, Table S2). To enhance the photocatalytic activity in aqueous solution, we studied the effect of modifying the QD surface. Ligand-free, charge-stabilized CdS nanocrystals $\left(\mathrm{QD}-\mathrm{BF}_{4}\right)$ were prepared from oleic acid capped CdS nanocrystals by following a modified reactive ligand stripping procedure using $\left[\mathrm{Me}_{3} \mathrm{O}\right] \mathrm{BF}_{4}$ in the presence
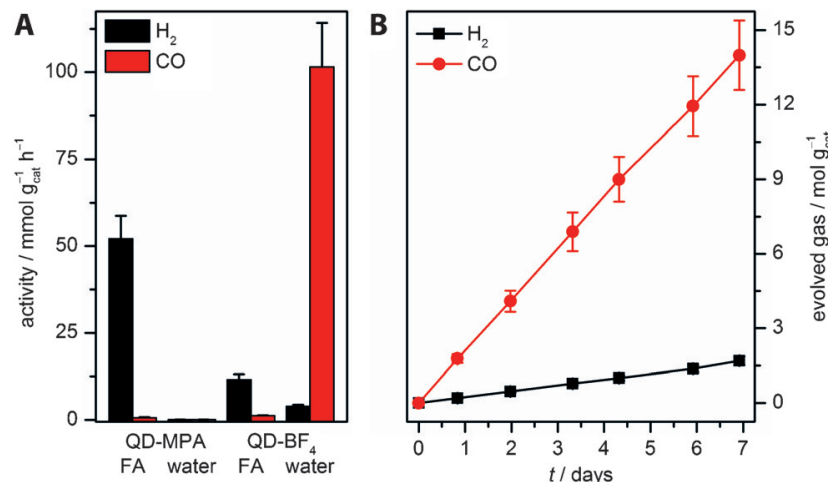

Figure 2. Photocatalytic dehydration of FA (AM1.5G, $100 \mathrm{mWcm}{ }^{-2}$, $\lambda>420 \mathrm{~nm}$ ): A) Effect of solvent on the product selectivity of CdS QDs in the absence of $\mathrm{CoCl}_{2}$ co-catalyst (see Table $\mathrm{S} 3$ for conditions);

B) long term activity of QD-BF 4 [0.0611 $\mu \mathrm{M}$ QD-BF $4\left(14.4 \mu \mathrm{g} \mathrm{mL}^{-1}\right)$, $4.0 \mathrm{M} \mathrm{NaHCO}$ in $2.5 \mathrm{M}$ aqueous $\mathrm{KOH} / \mathrm{CO}_{2} \mathrm{pH}$ 9.7].

of $N, N$-dimethylformamide (DMF) to remove the oleic acid capping groups. ${ }^{[35]}$ Ligand stripping led to a blue-shift of the absorption maximum indicative of a decrease in QD size (Figure S9B). This is presumably a result of etching by $\mathrm{BF}_{4}$ ions, as shown for CdTe QDs. ${ }^{[36]}$ Larger QD precursors $\left(\lambda_{\max }=\right.$ $466 \mathrm{~nm}, D=6.0 \pm 0.9 \mathrm{~nm}$ ) were, therefore, used to obtain QD-BF ${ }_{4}$ with a diameter similar to QD-MPA $\left(\lambda_{\max }=445 \mathrm{~nm}\right.$, $D=4.9 \pm 0.7 \mathrm{~nm}$, Figure $\mathrm{S} 9) . \mathrm{QD}-\mathrm{BF}_{4}$ showed a drastically enhanced photocatalytic FA-to-CO activity in water compared to QD-MPA (Figure 2A). Under optimized conditions, up to $102 \pm 13 \mathrm{mmolCOg}_{\text {cat }}{ }^{-1} \mathrm{~h}^{-1}$ are formed with $96.3 \pm$ $0.1 \%$ selectivity $\left(4.0 \mathrm{~m} \mathrm{NaHCO}_{2}\right.$ in $2.5 \mathrm{~m} \mathrm{KOH} / \mathrm{CO}_{2} \mathrm{pH} 9.7$; see Figures S10-S12 and Tables S7 and S8 for optimization details). In FA solution, $\mathrm{QD}-\mathrm{BF}_{4}$ showed a decomposition selectivity of FA towards $\mathrm{H}_{2}$ that was comparable to QDMPA, but with lower activity (Figure 2A, Table S2). The selectivity switchover to $\mathrm{CO}$ is, therefore, not a result of ligand removal, but promoted by the basic aqueous environment. This is further corroborated by a strong $\mathrm{pH}$-dependence of the product selectivity, with FA-to- $\mathrm{H}_{2}$ conversion becoming more pronounced in neutral and acidic solution (Figure S10, Table S7); the addition of MPA to QD-BF ${ }_{4}$ in aqueous formate solution did not affect the product selectivity (see below). The effects of water on the gas-phase photocatalytic FA decomposition have been previously documented. ${ }^{[37]}$

Aqueous $\mathrm{QD}-\mathrm{BF}_{4}$ is remarkably robust and sustained $\mathrm{CO}$ production over the course of one week with no detectable decrease in activity; more than $14 \mathrm{molCOg}_{\text {cat }}{ }^{-1}$ were generated, which corresponds to 3000000 turnovers per QD (Figure 2B, Table S9). No activity was seen in the absence of light (Table S2, entry 16; Figure S13), confirming that irradiation provides the necessary activation energy for formate dehydration. Since irradiation of CdS generates electron/hole pairs, we propose that the reaction mechanism is centered around the charge separation by the QD. Assuming that one photon is required to generate one $\mathrm{CO}$ molecule, a minimum EQY of $19.7 \pm 2.7 \%$ was recorded at $\lambda=460 \mathrm{~nm}$ (Table S10, see the Supporting Information for further details). Formate was established as the sole source of 
CO through IR spectroscopy by using ${ }^{13} \mathrm{C}$-labeled sodium formate (Figure S14). TEM analysis after catalysis indicates the formation of nanostructured aggregates (Figure S15). This was corroborated through an observed red-shift in the UV/ Vis spectrum (Figure S16, see above).

Addition of $\mathrm{CoCl}_{2}$ to $\mathrm{QD}-\mathrm{BF}_{4}$ or QD-MPA did not increase the photocatalytic activity in aqueous solution (Table S2), indicating that the CdS particle surface itself plays an essential role in the catalytic activity. Mechanistic studies were performed to further support this hypothesis (Tables $\mathrm{S} 11$ and S12). Addition of excess $\mathrm{Na}_{2} \mathrm{~S}$ to an active sample of $\mathrm{QD}-\mathrm{BF}_{4}$ in aqueous sodium formate solution resulted in a sudden drop in catalytic activity (Figure $3 \mathrm{~A}$ ),
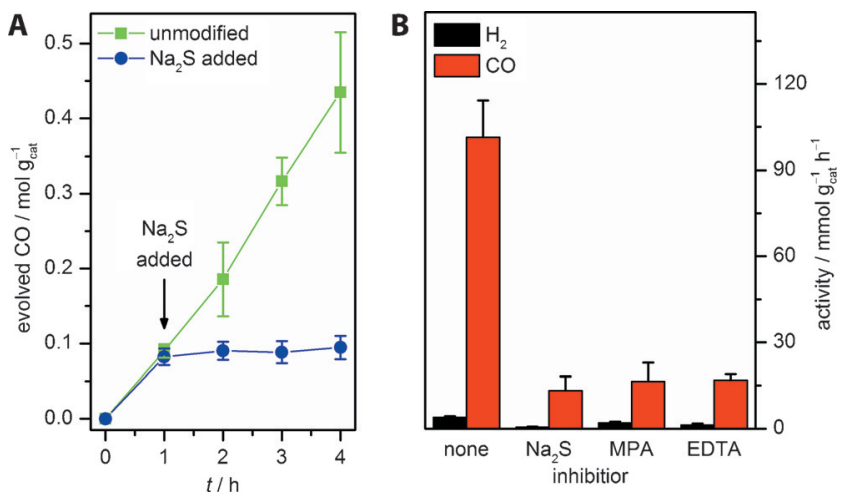

Figure 3. Effects of inhibitors on the photocatalytic dehydration of formate: A) In situ inhibition of photocatalytic activity by $\mathrm{Na}_{2} \mathrm{~S}$ addition (111 mM); B) comparison of different inhibitors $\left[100 \mathrm{~mW} \mathrm{~cm}^{-2}\right.$ AM1.5G, $\lambda>420 \mathrm{~nm} ; 0.0611 \mu \mathrm{M}$ QD-BF $4\left(14.4 \mu \mathrm{g} \mathrm{mL}^{-1}\right), 4.0 \mathrm{M}$ $\mathrm{NaHCO}_{2}, 2.5 \mathrm{M}$ aqueous $\mathrm{KOH} / \mathrm{CO}_{2} \mathrm{pH} 9.7 ; 111 \mathrm{~mm} \mathrm{Na} 2 \mathrm{~S}, 111 \mathrm{~mm}$ MPA, or $83.3 \mathrm{~mm} \mathrm{Na}{ }_{2}$ EDTA]. EDTA = ethylenediaminetetraacetate.

suggesting that sulfide ions block the catalytically active sites; addition of MPA resulted in a similar effect (Figure 3B). At the same time, no increase in $\mathrm{H}_{2}$ evolution was observed in either case, proving that $\mathrm{S}^{2-}$ ions are not simply acting as electron donors and that the addition of MPA has not resulted in a selectivity switch towards $\mathrm{H}_{2}$ production. We hypothesize that $\mathrm{Cd}$ ions form the active site for $\mathrm{CO}$ evolution. A similar decrease in CO evolution activity was observed when EDTA was added to selectively complex surface-bound $\mathrm{Cd}^{2+}$, providing further evidence of the crucial role of surface $\mathrm{Cd}^{2+}$ ions for dehydration activity. X-ray photoelectron spectra (XPS) of sulfide-poisoned QD-BF ${ }_{4}$ exhibit a slight shift of the $\mathrm{Cd}(3 \mathrm{~d})$ peaks to lower binding energies, very similar to the spectrum of QD-MPA (Figure S18, Table S13). In addition, a shoulder on the $\mathrm{Cd}(3 \mathrm{~d})$ signals, which is absent in unmodified QD-BF $\mathrm{B}_{4}$, is observed at a lower binding energy. Little effect on the Cd/S stoichiometry was observed by XPS (Table S13). These data indicate that $\mathrm{Na}_{2} \mathrm{~S}$ addition leads to a distortion of the $\mathrm{Cd}$ environment. The resemblance of the poisoned environment to that of inactive QD-MPA suggests that the active site is Cd-based. Previous studies on thermal FA decomposition have established the importance of surface effects, ${ }^{[38]}$ such as $\mathrm{H}_{2} \mathrm{O}$ coverage ${ }^{[39]}$ and surface acidity/ basicity, ${ }^{[40]}$ on the activity and selectivity.
In summary, we have developed an inexpensive and highly active photocatalyst system for sunlight-driven conversion of formic acid with controlled selectivity and long-term stability. Ligand-capped CdS quantum dots with a cobalt co-catalyst generate $\mathrm{H}_{2}$ with unprecedented activity and $>99 \%$ selectivity when dispersed in formic acid at room temperature. In contrast, $\mathrm{CO}$ formation is strongly favored in aqueous solution after ligand stripping and proceeds with high activity and efficiency. With this first example of selective photocatalytic formic acid to $\mathrm{CO}$ conversion, we introduce formic acid as a renewable $\mathrm{CO}$ storage material with more than $60 \mathrm{wt} \%$ capacity. This work demonstrates that careful matching of engineered particle surfaces with optimized reaction media enables a novel flexibility in the sustainable use of formic acid to generate valuable chemical feedstocks.

Keywords: CdS · formic acid · hydrogen · photocatalysis . quantum dots

How to cite: Angew. Chem. Int. Ed. 2015, 54, 9627-9631 Angew. Chem. 2015, 127, 9763-9767

[1] a) J. O’M. Bockris, Science 1972, 176, 1323; b) Q.-L. Zhu, Q. Xu, Energy Environ. Sci. 2015, 8, 478-512; c) A. F. Dalebrook, W. Gan, M. Grasemann, S. Moret, G. Laurenczy, Chem. Commun. 2013, 49, 8735-8751.

[2] a) S. Enthaler, J. von Langermann, T. Schmidt, Energy Environ. Sci. 2010, 3, 1207-1217; b) R. Williams, R. S. Crandall, A. Bloom, Appl. Phys. Lett. 1978, 33, 381-383.

[3] a) S. Moret, P. J. Dyson, G. Laurenczy, Nat. Commun. 2014, 5, 4017; b) K. Schuchmann, V. Müller, Science 2013, 342, 1382 1385 ; c) M. S. Jeletic, M. T. Mock, A. M. Appel, J. C. Linehan, J. Am. Chem. Soc. 2013, 135, 11533-11536; d) S. Wesselbaum, U. Hintermair, W. Leitner, Angew. Chem. Int. Ed. 2012, 51, 85858588; Angew. Chem. 2012, 124, 8713-8716; e) J. F. Hull, Y. Himeda, W.-H. Wang, B. Hashiguchi, R. Periana, D. J. Szalda, J. T. Muckerman, E. Fujita, Nat. Chem. 2012, 4, 383-388; f) R. Langer, Y. Diskin-Posner, G. Leitus, L. J. W. Shimon, Y. BenDavid, D. Milstein, Angew. Chem. Int. Ed. 2011, 50, 9948-9952; Angew. Chem. 2011, 123, 10122-10126; g) C. Federsel, A. Boddien, R. Jackstell, R. Jennerjahn, P. J. Dyson, R. Scopelliti, G. Laurenczy, M. Beller, Angew. Chem. Int. Ed. 2010, 49, $9777-$ 9780; Angew. Chem. 2010, 122, 9971 -9974; h) R. Tanaka, M. Yamashita, K. Nozaki, J. Am. Chem. Soc. 2009, 131, 1416814169.

[4] a) X. Lu, D. Y. C. Leung, H. Wang, M. K. H. Leung, J. Xuan, ChemElectroChem 2014, 1, 836-849; b) S. Zhang, P. Kang, T. J. Meyer, J. Am. Chem. Soc. 2014, 136, 1734-1737; c) P. Kang, S. Zhang, T. J. Meyer, M. Brookhart, Angew. Chem. Int. Ed. 2014, 53, 8709-8713; Angew. Chem. 2014, 126, 8853-8857; d) Y. Chen, M. W. Kanan, J. Am. Chem. Soc. 2012, 134, 1986-1989.

[5] a) A. Bassegoda, C. Madden, D. W. Wakerley, E. Reisner, J. Hirst, J. Am. Chem. Soc. 2014, 136, 15473-15476; b) T. Reda, C. M. Plugge, N. J. Abram, J. Hirst, Proc. Natl. Acad. Sci. USA 2008, 105, 10654-10658.

[6] a) W. Wang, M. Niu, Y. Hou, W. Wu, Z. Liu, Q. Liu, S. Ren, K. N. Marsh, Green Chem. 2014, 16, 2614-2618; b) J. Albert, R. Wölfel, A. Bösmann, P. Wasserscheid, Energy Environ. Sci. 2012, 5, 7956 -7962; c) J. Yun, F. Jin, A. Kishita, K. Tohji, H. Enomoto, J. Phys. Conf. Ser. 2010, 215, 012126.

[7] a) Q.-L. Zhu, N. Tsumori, Q. Xu, Chem. Sci. 2014, 5, 195-199; b) Y.-L. Qin, J.-W. Wang, Y.-M. Wu, L.-M. Wang, RSC $A d v$. 2014, 4, 30068-30073; c) K. Jiang, K. Xu, S. Zou, W.-B. Cai, J. Am. Chem. Soc. 2014, 136, 4861 -4864; d) Y. Chen, Q.-L. Zhu, N. 
Tsumori, Q. Xu, J. Am. Chem. Soc. 2015, 137, 106-109; e) Z.-L. Wang, J.-M. Yan, Y. Ping, H.-L. Wang, W.-T. Zheng, Q. Jiang, Angew. Chem. Int. Ed. 2013, 52, 4406-4409; Angew. Chem. 2013, 125, 4502-4505; f) Y.-L. Qin, J. Wang, F.-Z. Meng, L.-M Wang, X.-B. Zhang, Chem. Commun. 2013, 49, 10028-10030; g) Q.-Y. Bi, X.-L. Du, Y.-M. Liu, Y. Cao, H.-Y. He, K.-N. Fan, J. Am. Chem. Soc. 2012, 134, 8926-8933; h) K. Tedsree, T. Li, S. Jones, C. W. A. Chan, K. M. K. Yu, P. A. J. Bagot, E. A. Marquis, G. D. W. Smith, S. C. E. Tsang, Nat. Nanotechnol. 2011, 6, $302-$ 307.

[8] a) J. H. Barnard, C. Wang, N. G. Berry, J. Xiao, Chem. Sci. 2013, 4, 1234-1244; b) Y. Maenaka, T. Suenobu, S. Fukuzumi, Energy Environ. Sci. 2012, 5, 7360-7367; c) B. Loges, A. Boddien, H. Junge, M. Beller, Angew. Chem. Int. Ed. 2008, 47, 3962-3965; Angew. Chem. 2008, 120, 4026-4029; d) C. Fellay, P. J. Dyson, G Laurenczy, Angew. Chem. Int. Ed. 2008, 47, 3966-3968; Angew. Chem. 2008, 120, 4030-4032; e) Y. Gao, M. C. Jennings, R. J. Puddephatt, Organometallics 2001, 20, 1882-1888.

[9] a) M. C. Neary, G. Parkin, Chem. Sci. 2015, 6, 1859-1865; b) S. Enthaler, A. Brück, A. Kammer, H. Junge, E. Irran, S. Gülak, ChemCatChem 2015, 7, 65-69; c) C. Chauvier, A. Tlili, C. Das Neves Gomes, P. Thuéry, T. Cantat, Chem. Sci. 2015, 6, 2938-2942; d) F. Bertini, I. Mellone, A. Ienco, M. Peruzzini, L. Gonsalvi, ACS Catal. 2015, 5, 1254-1265; e) N. Scotti, R. Psaro, N. Ravasio, F. Zaccheria, RSC Adv. 2014, 4, 61514-61517; f) T. W. Myers, L. A. Berben, Chem. Sci. 2014, 5, 2771-2777; g) E. A. Bielinski, P. O. Lagaditis, Y. Zhang, B. Q. Mercado, C. Würtele, W. H. Bernskoetter, N. Hazari, S. Schneider, J. Am. Chem. Soc. 2014, 136, 10234-10237; h) T. Zell, B. Butschke, Y. Ben-David, D. Milstein, Chem. Eur. J. 2013, 19, 8068-8072; i) A Boddien, D. Mellmann, F. Gärtner, R. Jackstell, H. Junge, P. J. Dyson, G. Laurenczy, R. Ludwig, M. Beller, Science 2011, 333, $1733-1736$.

[10] a) K. Tsutsumi, N. Kashimura, K. Tabata, Silicon 2015, 7, 43-48; b) Y.-Y. Cai, X.-H. Li, Y.-N. Zhang, X. Wei, K.-X. Wang, J.-S Chen, Angew. Chem. Int. Ed. 2013, 52, 11822-11825; Angew. Chem. 2013, 125, 12038-12041; c) G. Halasi, G. Schubert, F. Solymosi, J. Phys. Chem. C 2012, 116, 15396-15405.

[11] a) Z. Zheng, T. Tachikawa, T. Majima, J. Am. Chem. Soc. 2015, 137, $948-957$; b) Z. Zhang, S.-W. Cao, Y. Liao, C. Xue, Appl. Catal. B 2015, 162, 204-209.

[12] a) X. Zhang, M. Yang, J. Zhao, L. Guo, Int. J. Hydrogen Energy 2013, 38, 15985-15991; b) C. W. Lee, Asian J. Chem. 2013, 25 , $5861-5864$; c) Y. Li, F. He, S. Peng, D. Gao, G. Lu, S. Li, J. Mol. Catal. A 2011, 341, 71-76; d) T. Chen, G. Wu, Z. Feng, G. Hu, W. Su, P. Ying, C. Li, Chin. J. Catal. 2008, 29, 105-107.

[13] G. Halasi, G. Schubert, F. Solymosi, Catal. Lett. 2012, 142, 218 223.

[14] B. Loges, A. Boddien, H. Junge, J. R. Noyes, W. Baumann, M. Beller, Chem. Commun. 2009, 4185-4187.

[15] a) B. Zielinska, M. Janus, R. J. Kalenczuk, Cent. Eur. J. Chem. 2013, 11, 920-926; b) V. Lanese, D. Spasiano, R. Marotta, I. Di Somma, L. Lisi, S. Cimino, R. Andreozzi, Int. J. Hydrogen Energy 2013, 38, 9644-9654; c) A. Boddien, B. Loges, F. Gärtner, C. Torborg, K. Fumino, H. Junge, R. Ludwig, M. Beller, J. Am. Chem. Soc. 2010, 132, 8924-8934; d) S. Kakuta, T. Abe, ACS Appl. Mater. Interfaces 2009, 1, 2707-2710; e) M. Onishi, J. Mol. Catal. 1993, 80, 145-149; f) D. E. Linn, Jr., R. B. King, A. D. King, Jr., J. Mol. Catal. 1993, 80, 151-163.

[16] CRC Handbook of Chemistry and Physics, 95th ed. (Ed.: W. M. Haynes), CRC Press/Taylor and Francis, Boca Raton, FL, 2015.

[17] A. P. Alivisatos, J. Phys. Chem. 1996, 100, 13226-13239.

[18] M. R. Kim, D. Ma, J. Phys. Chem. Lett. 2015, 6, 85-99.

[19] a) T. Simon, N. Bouchonville, M. J. Berr, A. Vaneski, A. Adrović, D. Volbers, R. Wyrwich, M. Döblinger, A. S. Susha,
A. L. Rogach, F. Jäckel, J. K. Stolarczyk, J. Feldmann, Nat. Mater. 2014, 13, $1013-1018$; b) C.-B. Li, Z.-J. Li, S. Yu, G.-X. Wang, F. Wang, Q.-Y. Meng, B. Chen, K. Feng, C.-H. Tung, L.-Z. Wu, Energy Environ. Sci. 2013, 6, 2597-2602; c) L. Huang, X. Wang, J. Yang, G. Liu, J. Han, C. Li, J. Phys. Chem. C 2013, 117, 11584-11591; d) M. A. Holmes, T. K. Townsend, F. E. Osterloh, Chem. Commun. 2012, 48, 371-373; e) Z. Han, F. Qiu, R. Eisenberg, P. L. Holland, T. D. Krauss, Science 2012, 338, 1321 1324.

[20] I. Willner, Z. Goren, J. Chem. Soc. Chem. Commun. 1986, $172-$ 173.

[21] a) H. M. Yeh, S. L. Lo, M. J. Chen, H. Y. Chen, Water Sci. Technol. 2014, 69, 1676-1681; b) W. Tang, D. Jing, L. Guo, MRS Online Proc. Libr. 2011, 1326.

[22] X. Wang, W.-C. Peng, X.-Y. Li, Int. J. Hydrogen Energy 2014, 39, $13454-13461$.

[23] a) Y. Li, L. Tang, S. Peng, Z. Li, G. Lu, CrystEngComm 2012, 14, 6974-6982; b) Y. Li, Y. Hu, S. Peng, G. Lu, S. Li, J. Phys. Chem. C 2009, 113, 9352-9358; c) S. Kambe, M. Fujii, T. Kawai, S. Kawai, F. Nakahara, Chem. Phys. Lett. 1984, 109, 105-109.

[24] Y. J. Zhang, L. Zhang, S. Li, Int. J. Hydrogen Energy 2010, 35, $438-444$.

[25] A. I. Nedoluzhko, I. A. Shumilin, V. V. Nikandrov, J. Phys. Chem. 1996, 100, 17544-17550.

[26] F. Fischer, H. Tropsch, Brennst.-Chem. 1926, 7, 97-104.

[27] a) H. Konishi, K. Manabe, Synlett 2014, 25, 1971-1986; b) L. Wu, Q. Liu, R. Jackstell, M. Beller, Angew. Chem. Int. Ed. 2014, 53, 6310-6320; Angew. Chem. 2014, 126, 6426-6436.

[28] E. G. Graeber, D. S. Cryder, Ind. Eng. Chem. 1935, 27, 828-831.

[29] J. Aldana, N. Lavelle, Y. Wang, X. Peng, J. Am. Chem. Soc. 2005, $127,2496-2504$.

[30] W. W. Yu, L. Qu, W. Guo, X. Peng, Chem. Mater. 2003, 15, $2854-$ 2860.

[31] a) C. Gimbert-Suriñach, J. Albero, T. Stoll, J. Fortage, M.-N. Collomb, A. Deronzier, E. Palomares, A. Llobet, J. Am. Chem. Soc. 2014, 136, 7655-7661; b) A. Das, Z. Han, M. G. Haghighi, R. Eisenberg, Proc. Natl. Acad. Sci. USA 2013, 110, 1671616723.

[32] C. Jung, C. M. Sánchez-Sánchez, C.-L. Lin, J. Rodríguez-López, A. J. Bard, Anal. Chem. 2009, 81, 7003-7008.

[33] T. J. Kemp, W. A. Waters, Proc. R. Soc. London Ser. A 1963, 274 , $480-499$.

[34] A. S. Feiner, A. J. McEvoy, N. Vlachopoulos, M. Grätzel, Ber. Bunsen-Ges. 1987, 91, 399-402.

[35] E. L. Rosen, R. Buonsanti, A. Llordes, A. M. Sawvel, D. J. Milliron, B. A. Helms, Angew. Chem. Int. Ed. 2012, 51, 684-689; Angew. Chem. 2012, 124, 708-713.

[36] J. Liu, X. Yang, K. Wang, D. Wang, P. Zhang, Chem. Commun. 2009, 6080-6082.

[37] a) K. L. Miller, J. L. Falconer, J. W. Medlin, J. Catal. 2011, 278, 321 - 328; b) K. L. Miller, C. W. Lee, J. L. Falconer, J. W. Medlin, J. Catal. 2010, 275, 294-299.

[38] J. Cho, S. Lee, J. Han, S. P. Yoon, S. W. Nam, S. H. Choi, K.-Y. Lee, H. C. Ham, J. Phys. Chem. C 2014, 118, 22553-22560.

[39] R. Zhang, H. Liu, B. Wang, L. Ling, J. Phys. Chem. C 2012, 116, $22266-22280$.

[40] P. Mars, J. J. F. Scholten, P. Zwietering, in Adv. Catal., Vol. 14 (Eds.: H. P. D. D. Eley, B. W. Paul), Academic Press, San Diego, 1963, pp. $35-113$.

Received: March 25, 2015

Published online: July 16, 2015 